\title{
The Literature Review of De Novo Programming
}

\author{
D.O.I - 10.51201/Jusst12566 \\ http://doi.org/10.51201/Jusst12566
}

Naglaa Ragaa Saeid Hassan

\begin{abstract}
Associate Professor - Dept. of Operations Research and Management, Faculty of Statistical Studies and Research, Cairo University, Egypt.
\end{abstract}

\begin{abstract}
De novo programming (DNP) is a system design approach which links system flexibility efficient and optimal system design. It shows that within single or multi-objective decision making framework. DNP allows the decision maker to achieve an ideal or metaoptimal system performance, or improve the performance of compromise solutions through the modification of the feasible region of decision alternatives. This paper considers a brief review of DNP, which provides a brief insight DNP and its applications.
\end{abstract}

Keywords: De Novo Programming - Optimization techniques -Redesign Systems Resources allocation - The Optimum path ratios - Improving the Performance

\section{Introduction}

Traditional linear programming (LP) is a good way to obtain the optimal allocation of limited resources. But the modern view has been shifted from an allocation of the limited or fixed resources optimally for a given system to design an optimal system for the existed resources. The process of optimization is pivotal to the areas of economics, engineering, as well as management and business, etc. [1] presented the concept of DNP to deal with optimal designing of a system where all the objectives are optimized simultaneously, no trade-offs among the objectives are necessary and no resources are left unused. So, the major characteristic of DNP is to realize the optimal system design instead of optimizing a given system. In 1986, [2] introduced a new way of resolving multiple-criteria decision making problems depending on the DNP to pursue the requirements of modern production which characterized by no-waste, no-buffer, just-in-time operations, full utilization of scarce resources,...etc.[3] explained the purpose of optimizing the system not just to improve the performance of a given system but rather to find the best one (design an optimal system). Many researches rarely dealt with system design. Rather, they focused on valuation of a given system, searching for decision variables that maximize a single or multiple objectives. This review introduces to discuss a theory, methodology and different techniques of DNP and its applications.This paper is as follows: In Section 2 introduces "The De Novo programming", its general model, formulation, and optimum-path ratios for selecting the optimal system designs to solve DNP problems. Section 3 represents "A review over De Novo Programming" which includes a brief review insight the DNP. Section 4 represents "Theanalysis \& summary of literature review" including the applications used and the methods or techniques applied. We also show the percentage of each type of applications on the DNP. The conclusion is given in Section 5.

\section{The De Novo Programming}

In 1980, [1] presented the concept of DNP to deal with optimal designing of a system. This method was first designed for single-criterion decision making and later it is extended to multi- 
criteria (MC) decision-making, containing the maximizing type of objectives only [4]. [5] considered the general model of DNP by denoting the available amounts of resources $\boldsymbol{b}_{\boldsymbol{i}}, \boldsymbol{i}=$ $\mathbf{1}, \ldots, \boldsymbol{m}$ and their corresponding prices $\boldsymbol{p}_{\boldsymbol{i}}$, then $\boldsymbol{p}_{\mathbf{1}} \boldsymbol{b}_{\mathbf{1}}+\cdots+\boldsymbol{p}_{\boldsymbol{m}} \boldsymbol{b}_{\boldsymbol{m}}$ represents the total valuation of resources. The individual $\boldsymbol{b}_{\boldsymbol{i}}$ 's are not "given" constants but rather decision variables affecting the value of the objective functions involved. Suppose that $\boldsymbol{B}$ indicates to the available budget for the purchases of the resources. We want to maximize profits $\boldsymbol{C}$ for single or multiple objective problems, and the representation of the resource allocation (RA) can be formulated as in the following LP model:

$$
\begin{aligned}
& \text { Maximize } Z=C X \\
& \text { s.t.AX }-\boldsymbol{b} \leq \mathbf{0}, p b \leq B, X \geq 0
\end{aligned}
$$

Where $C \in R^{q * n}$ and $A \in R^{m * n_{1}}$ represent matrices with dimensions $q \times n$ and $m \times n$ respectively, and $b \in R^{m}$ with m-dimensional unknown resource vector, $X \in R^{n}$ is n-dimensional vector of decision variables, $p \in R^{m}$ is the vector of the unit prices of $\mathrm{m}$ resources, and $\boldsymbol{B}$ is the given total available budget.

Solving problem eq. (1) means finding the optimal allocation of B so that the corresponding to resource portfolio $\mathrm{b}$ maximizes simultaneously the values $Z=C X_{\text {of }}$ the product mix $\mathrm{x}$. It is obviously that to transform problem (1) into problem (2) as follows:

$$
\begin{aligned}
\text { Maximize } Z & =C X \\
\text { s.t. } V X & \leq B, X \geq 0
\end{aligned}
$$

Where $Z=\left(z_{1}, \ldots, z_{q}\right) \in \mathrm{R}^{q}$ and $V=\left(v_{1}, \ldots, v_{n}\right)=p A \in \mathrm{R}^{n}$

Let $\boldsymbol{z}_{\boldsymbol{k}^{*}}=\max \mathbf{z}_{\boldsymbol{k}}, \boldsymbol{k}=\mathbf{1}, \ldots, \boldsymbol{q}$, be the optimal value for $\mathbf{k}^{\text {th }}$ objective of Problem (2) subject to $V X \leq B, X \geq 0, X \geq 0$.Let $z^{*}=\left(z_{1 *}, \ldots, z_{q^{*}}\right)$ be the q-objective value for the ideal system with respect to $B$. Then, a meta-optimum problem (problem (3)) can be constructed as follows:

$$
\begin{array}{r}
\text { Minimize } B=V x \\
\text { s.t } C x \geq Z^{*}, X \geq 0
\end{array}
$$

Solving problem (3) yields $x^{*}, B^{*}\left(=\mathrm{V} x^{*}\right)$ and $b^{*}\left(=\mathrm{A} x^{*}\right)$. The value $\mathbf{b}^{*}$ identifies the minimum budget to achieve $\mathbf{Z}^{*}$ through $\mathbf{x}^{*}$ and $\mathbf{b}^{*}$. At $B^{*} \leq B$, the optimal design reached. Since $B^{*} \geq B$, the optimum-path ratio for achieving the ideal performance $\mathbf{Z}^{*}$ for a given budget level $\boldsymbol{B}$ is defined as in (4):

$$
\boldsymbol{r}^{*}=\frac{\boldsymbol{B}}{\boldsymbol{B}^{*}}
$$

And establish the optimal system design as (x, b, Z), where $x=r^{*} x^{*}, b=r^{*} b^{*}$ and $Z=r^{*} Z^{*}$. The optimum-path ratio $\boldsymbol{r}^{*}$ provides an effective and fast tool for efficient optimal redesign of large-scale linear systems.

\subsection{The optimum-path ratios}

[6] summarized several optimum-path ratios depending on the basic optimum-path ratio $\boldsymbol{r}^{*}$, as alternatives for selecting the optimal system designs to solve DNP problems. She summarized the relationships between the budgets $B^{* *}, B^{*}, B$, and $b_{j}^{k}$ that serve as the basis of the optimum-path study.

$$
B^{* *} \geq B^{*} \geq B \geq b_{j}^{k}, \text { for } k=1, \ldots, q
$$

The Theorem in eq 5 could be defined in six types of optimum-path ratios as follows: 


$$
\begin{array}{lll}
\text { (i) } r^{1}=\frac{B^{*}}{B^{* *}} ; & \text { (ii) } r^{2}=\frac{B}{B^{* *}} ; & \text { (iii) } r^{3}=\frac{\sum \gamma_{k} b_{j k}^{k}}{B^{* *}} \\
\text { (iv) } r^{4}=\frac{B}{-} & \text { (v) } r^{5}=\underline{\sum \gamma_{k} b_{j k}^{k}} . & \text { (vi) } r^{6}=\underline{\sum \gamma_{k} b_{j k}^{k}}
\end{array}
$$

The above optimum-path ratios represent the basic optimum path ratio studied by Zeleny. Assume the given initial budget level $B$ in problem (1) or (2) can be replaced by either $B^{*}$ using these optimum-path ratios, the following optimal system designs can be established.
(i) $x^{1}=r^{1} x^{* *}$,
$b^{1}=r^{1} b^{* *}$
and $Z^{1}=r^{1} Z^{* *}$
(ii) $x^{2}=r^{2} x^{* *}$
$b^{2}=r^{2} b^{* *}$
and $Z^{2}=r^{2} Z^{* *}$
(iii) $x^{3}=r^{3} x^{* *}$,
$b^{3}=r^{3} b^{* *}$,
and $Z^{3}=r^{3} Z^{* *}$
(iv) $x^{4}=r^{4} x^{* *}$,
$b^{4}=r^{4} b^{* *}$,
and $Z^{4}=r^{4} Z^{* *}$
(v) $x^{5}=r^{5} x^{* *}$
$b^{5}=r^{5} b^{* *}$,
and $Z^{5}=r^{5} Z^{* *}$
(vi) $x^{6}=r^{6} x^{* *}$,
$b^{6}=r^{6} b^{* *}$,
and $Z^{6}=r^{6} Z^{\text {nd }}$

The meaning of the above optimal system design $\left(x^{\mathrm{i}}, b^{\mathrm{i}}, Z^{\mathrm{i}}\right)$ from 1 to 6 is that $b^{\mathrm{i}}$ represents the optimum portfolio of resources to be acquired at the current market prices, $p$, allows one to produce $x^{\mathrm{i}}$ and realize the multi-criteria performance $Z^{\mathrm{i}}$. When the problem (1) or (2) is actually applied to solve real world problems, these designs may be presented to the decision maker as candidates for the final optimal system design.

\section{A Historical Review Over De Novo Programming}

In this section, the review of DNP for the various optimization problems is presented.[1] developed an approach, known as the DNP model. This model seeks for an 'optimal system' by reshaping the feasible solution set, reaching to the optimality. Thus, the concept of DNP is to design an optimal system instead of finding an optimum in a given system with fixed resources. In 1981, [4], [7] presented another two papers about DNP. First one is about considering the main shortcoming of LP which is neither its linearity assumption, nor inefficiency, nor its singleobjective but it is its inability to design an optimal system. This method was first designed for single-criterion decision making. The second papers, it is considered about the difference between "optimizing a given system" and "designing an optimal one" showing the new concepts for optimality, presenting new ways of resolving Multiple Criteria Decision Making (MCDM) conflicts \& new conditions for optimal. In 1986, [2] extended the model to MCDM, containing the maximizing type of objectives only resolving MCDM problems using DNP for optimal and continuous system improvement. [8] considered the concept of an optimally designed for productmix system formulating the corresponding duality theory. They showed that although the system is degenerate, the optimality of design "overcomes" its own degeneracy allowing unique valuation of all resources. [9] introduced the subject of soft optimization using DNP formulation of single and MOLP optimization techniques which incorporate MOs for increasing the utility of forest planning models. [10] showed that the DNP formulation deal with the best mixture of input specified as well as the best mixture of the output. [11] illustrated the potential use of designing optimal forest systems in the face of conflictive objectives. A MOLP model is used to illustrate this approach reaching to compromise solution under DNP conditions. [3] explained the purpose of optimizing the system, it is not just to improve the performance of a given system but rather to find the best system configuration itself (design an optimal system). Thus, Zeleny presented a theory and methodology of optimal system design embodied in DNP.

[12] \& [13] extended Zeleny's basic method to identify fuzzy system design for de Novo problems by considering the fuzziness in coefficients. They proposed a two-step fuzzy approach based on the ideal and negative ideal solutions. They showed that this approach is very efficient and applicable to the general MCDNP. They also formulated and analyzed a fuzzy version of this problem. Also, [14] developed fuzzy goals and coefficients for the DNP model depending on a numerical approach which could be solved as either linear or nonlinear programming problems. [15] introduced fuzzy DNP as Fuzzy Optimization. [16] proposed several optimum-path ratios for enforcing different budget levels of resources so as to find alternative optimal system designs for solving MCDNP problems. The problem is formulated as DNP with a given initial budget level and 
an optimal pattern preferred by the decision maker. An interactive algorithm is developed to continuously reshape the problem for matching the optimal pattern. [17] considered MC production planning using DNP approach. The production plan for a real system is defined taking into account financial constraints and given objective functions. This study illustrated how to design an optimal production model reaching to the optimal functioning and maintenance. [16] presented MCDNP to formulate and solve problems of system design that involve multiple decision makers and a possible debt. In the framework the decision maker has involved his or her own preference for the budget availability level associated with MC under consideration. The model allows flexibility for decision makers to borrowadditional money from the bank with a fixed interest rate so as to keep the production process feasible. [18]considered the two fundamental dimensions of management: what is your system and how do you operate it. The main foundation of the competitive advantage already recognized managing the optimally designed, high-productivity, and tradeoffs-free systems. He summarized the basic formalism applying DNP.

[19] presented the impossibility of optimization when crucial variables are given showing the eight basic concepts of optimality. He showed a more realistic problem of LP to be optimized with MO functions using DNP. [20] suggested an optimal resource portfolio using DNP. A numerical example demonstrated the criteria of strategic alliances. The authors explained the formation of strategic alliances providing solutions for RA in achieving the desired level.

[21] considered DNP problems by extending to a fuzzy dynamic programming problem. First, a traditional DNP problem is modified to DNP problem with multiple fuzzy goals, fuzzy constraints and multiple stages. Second, they regard this model of fuzzy multi-stage DNP problem as a fuzzy dynamic programming problem.

[22] introduced the use of MC approach in designing the optimal production system. They combined the MC and DNP in a productionmodel. Moreover, they applied in a real production system which produces various ferroalloys using a number of different raw materials. Lastly, the paper demonstrated how the usual MC problems could be handled in a different concept of optimization using DNP approach.

[23] proposed fuzzy MO dummy programming model to overcome the problems to achieve the goal such as the correct alliance partners and the appropriate RA. Depending on the numerical results, they suggested model to provide the best alliance cluster, the maximum synergy effects, and the optimal alliance satisfaction

[24] integrated information technology into instruction to build an education RA planning model using DNP. They expected building an efficient planning model for school education using DNP to achieve a desired level of RA with minimum cost. The efficiency planning model is reached to the optimal RA and also enhanced the performance of teaching activities.

[25] considered a combined DNP with MODM techniques to solve RA problems for Environment-watershed resource management. The model is designed from the DNP perspective to help environmental-watershed optimize their maintenance resource portfolio. [26] applied DNP as an alternative strategic alliance to achieve optimal RA in supply chain (SC) systems. They developed an efficient resource planning model for best optimal RA.[27] introduced inexact DNP approach to design an optimal water resources management system under uncertainty. The optimal supplies of good-quality of water are obtained in considering different revenue targets under a given budget.[28] introduced the essential multi-dimension of an economic Problem: Towards tradeoffs-free Economics. He used DNP through a feasible set of opportunities towards an optimal to tradeoffs-free configuration.[5] in the handbook of MC analysis explored some topics beyond traditional MCDM, he explained the simplest possible terms of what MO optimization is, defining the subject matter, and discussing the role of tradeoffs-based versus tradeoffs-free thinking.

[29] presented approaches for solving the MODNP. He also introduced possible extensions, methodological, and real applications.

[30]applied DNP as a methodology of optimal system design by reshaping the feasible sets in linear systems. He summarizes the basic concepts of the DNP optimization, extensions, 
methodological and actual applications. He formulated\& solved the SC problem using the DNP approach.

[31] introduced a new interactive framework for sensitivity-informed de Novo planning to confront the deep uncertainty within water management problems. The framework couples global sensitivity analysis using Sobol variance decomposition with MO evolutionary algorithms to generate planning alternatives. The study examined a single city's water supply in Texas, using 6 objectives problem formulations that have increasing decision complexity for 10 years planning horizon. The planning framework showed how to adaptively improve the value and robustness of the problem formulations. [32] suggested a new approach for solving multi-stage and MODM problem using DNP.[33] applied MOGP for solving priority with the pavement maintenance works in the pavement management system. The DNP is used reaching to the ideal point. They tried to use this method to solve Taiwan Freeway's maintenance work programming. The analytical results completed by DNP. The performance is improved by budget. So DNP is applied on pavement maintenance as a new way to solve the problem.

[34] presented DNP as a new technique for optimal system design. The advantage of the proposed approach is that it requires less number of variables to be introduced in the solution procedure and thus reducing the processing time in comparison with the existing method.

[35] suggested Min-max Goal Programming (GP) approaches using positive and negative ideals to solve the MODNP problem.

[36] considered brief history of De Novo technique, mathematical definitions of MCDNP, and global criterion method is given with their respective principles. They presented a real firm applications given the budget for the same level of production is significantly can be reduced by an improvement in problem constraints.

[37] proposed planning water resources systems under uncertainty using an interval-fuzzy DNP method.

[38] adopted the DNP for achieving firm's strategic goal. They used the DNP to help firms finding out an optimal resource integration based on financial consideration.

They planed model provided reliable systematize approach that combines alliances from external resources and change them to internal resources application. The project team adopting open innovation concept through outsourcingreduces design cost and enhances design performance. DNP not only obtains optimal resource integration but also promotes the conceptual of strategic alliances for firm's cooperation between each other.

[39] presented the capacity determination in a closed-loop SC network when a queuing system is established in the reverse flow. Since the queuing system imposes costs, the decision maker faces the challenge to determine the capacity of facilities which represent a compromise between the queuing costs and the fixed costs of opening new facilities.They developed DNP approach to determine the capacity of recovery facilities in the reverse flow using a mixed integer nonlinear programming model integrated with the DNP and uncertainty of the parameters.

[40] considered a bi-objective integrated model for supplier location-allocation, capacity allocation and supplier selection, and order allocation problems in two level SCs. First, they proposed a singleobjective model to minimize the total costs. Second, they used DNP to determine the optimal capacity of selected supplier(s).[41] presented an alternative approach for solving the general MODNP Problem under fuzzy environment in one step using Luhandjula's compensatory $\boldsymbol{\mu}_{\boldsymbol{\theta}^{-}}$ operator.

The solution obtained represents an efficient solution under the assumption. The method has been illustrated by a numerical example. They showed that the suggested methodology requires less processing time in comparison with the existing ones because the problem can be solved in one step only. To make the problem more flexible, instead of crisp coefficients, fuzzy, type 2 fuzzy coefficients can be considered. 
[42] considered the potential use of the meta-GP approach for solving MCDNP problems. The objectives of the DNP problem are converted into meta-goals during formulation to arrive at the most satisfactory decision in the MODM context. This approach is shown superior. It provides decision-makers with more flexibility in expressing their preferences, by merging the original explicit goals as meta-goals. The proposed model is provided the best plan for the exploitation of wind energy sourcing.

[43]developed a Fuzzy MCDNP problem. The fuzzy parameters are characterized by fuzzy numbers. A fuzzy GP approach is applied for the corresponding MCDNP ( $\alpha$ - MDNLP) problem defining suitable membership functions and aspiration levels. The advantage of the approach is that the decision maker's role is only the specification of the level $\alpha$ and hence evaluate the $\alpha-$ coefficient solution for limitation of his/her incomplete knowledge about the problem domain.[44] proposed weighted GP approach for solving MODNP problems. In this approach, the weighted GP technique has been used, where only one deviation variable has been taken. [45] suggested the goal objectives using the average concept for objectives that have the same interests. Determination of goals with an average each concept considers the objectives of other goals in determining a goal. Determination of goal objectives using the average concept applied to the GP to solvethe MO problem of the DNP. The computational results with benchmark problems show that the proposed method gives satisfactory results and more practical work.

\section{Analysis of The Literature Review}

From the previous analysis of the Literature Review in Table 1, the DNP is a good field for building the optimal system design. Figure 1 represents the different area of applications covered using DNP technique as follows:

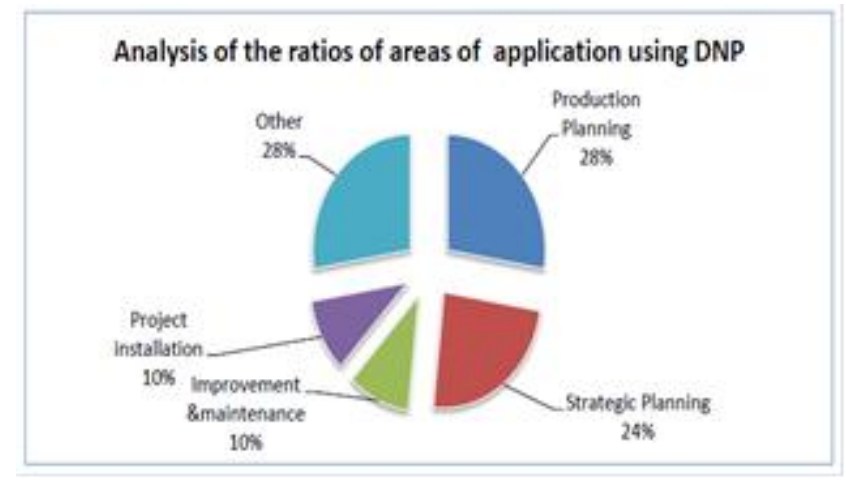

Figure 1. The ratios of areas of application using De Novo Programming

Table 1 Analysis of the Literature Review 


\begin{tabular}{|c|c|c|c|c|}
\hline No & $\begin{array}{l}\text { Author(s) } \\
\text { Ref No. }\end{array}$ & Application & $\begin{array}{l}\text { Single / multi } \\
\text { - objectives }\end{array}$ & Method \\
\hline 1 & [1] & $\begin{array}{l}\text { Numerical } \\
\text { examples }\end{array}$ & $\begin{array}{c}\text { Single } \\
\text { objective }\end{array}$ & $\begin{array}{l}\text { He suggested the concept } \\
\text { of DNP to design an } \\
\text { optimal system instead of } \\
\text { finding an optimum in a } \\
\text { given system with fixed } \\
\text { resources. }\end{array}$ \\
\hline 2 & [4] & $\begin{array}{l}\text { Resources } \\
\text { allocation }\end{array}$ & $\begin{array}{c}\text { Single } \\
\text { objective }\end{array}$ & $\begin{array}{l}\text { He showed that the main } \\
\text { shortcoming of L.P is its } \\
\text { inability to design an } \\
\text { optimal system. Thus, this } \\
\text { method was first designed } \\
\text { for single-criterion DML. }\end{array}$ \\
\hline 3 & [7] & $\begin{array}{l}\text { Numerical } \\
\text { examples }\end{array}$ & $\begin{array}{l}\text { Multiple } \\
\text { Criteria } \\
\text { Analysis }\end{array}$ & $\begin{array}{l}\text { He showed the difference } \\
\text { between "optimizing a } \\
\text { given system" and } \\
\text { "designing an optimal } \\
\text { system" presenting the } \\
\text { new concepts of optimality. }\end{array}$ \\
\hline 4 & [2] & $\begin{array}{l}\text { Production } \\
\text { system } \\
\text { continuous }\end{array}$ & $\begin{array}{l}\text { Multiple } \\
\text { Criteria }\end{array}$ & $\begin{array}{l}\text { He applied DNP to resolve } \\
\text { MCDM model with } \\
\text { conflicts and continuous } \\
\text { system. }\end{array}$ \\
\hline
\end{tabular}


Continue Table 1

\begin{tabular}{|c|c|c|c|c|}
\hline No & $\begin{array}{l}\text { Author(s) } \\
\text { Ref No. }\end{array}$ & Application & $\begin{array}{l}\text { Single / multi } \\
\text { - objectives }\end{array}$ & Method \\
\hline 5 & [8] & $\begin{array}{l}\text { Resources } \\
\text { allocation }\end{array}$ & $\begin{array}{l}\text { Single } \\
\text { objective / } \\
\text { duality }\end{array}$ & $\begin{array}{l}\text { They considered the concept } \\
\text { of optimally designed } \\
\text { formulating } \\
\text { corresponding duality theory. } \\
\text { They showed that although } \\
\text { the system is degenerate, the } \\
\text { optimality of design } \\
\text { "orercomes" its own } \\
\text { degeneracy and allons unique } \\
\text { valuation of all resources. }\end{array}$ \\
\hline 6 & [9] & $\begin{array}{c}\text { Forest } \\
\text { planuing model }\end{array}$ & $\begin{array}{l}\text { Single and } \\
\text { Multi objective } \\
\text { / Ctility }\end{array}$ & $\begin{array}{l}\text { They introduced the subject } \\
\text { of soft optimization using } \\
\text { DNP formulation of single } \\
\text { and MO optimization } \\
\text { problems. }\end{array}$ \\
\hline 7 & [10] & $\begin{array}{l}\text { Resources } \\
\text { allocation }\end{array}$ & $\begin{array}{l}\text { Multiple } \\
\text { criteria } \\
\text { decision } \\
\text { making }\end{array}$ & $\begin{array}{l}\text { He showed that the DXP } \\
\text { formalation deal with the best } \\
\text { mixture of inpost as well as the } \\
\text { best mixture of the output. }\end{array}$ \\
\hline 8 & [11] & Forest system & $\begin{array}{l}\text { A multiple } \\
\text { objective LP } \\
\text { model }\end{array}$ & $\begin{array}{l}\text { They designed optimal forest } \\
\text { syste um with conflictive } \\
\text { objectives. A multiple } \\
\text { objective LP model is used.A } \\
\text { compromise solution under } \\
\text { De Novo conditions is } \\
\text { discussed. }\end{array}$ \\
\hline 9 & [3] & $\begin{array}{l}\text { Numerical } \\
\text { example }\end{array}$ & $\begin{array}{l}\text { multiple } \\
\text { criteria } \\
\text { decision } \\
\text { making }\end{array}$ & $\begin{array}{l}\text { A the ory \& methodology of } \\
\text { optimal system desigu } \\
\text { embodied using DNP. }\end{array}$ \\
\hline 10 & {$[12][13]$} & $\begin{array}{l}\text { Numerical } \\
\text { example }\end{array}$ & $\begin{array}{c}\text { Fuzzy multi- } \\
\text { criteria }\end{array}$ & $\begin{array}{l}\text { They extended Zeleny's basic } \\
\text { wethod to ideutify fuzzy } \\
\text { system design cousidering the } \\
\text { fuzriness in coefficients. They } \\
\text { proposed a two-step fuzzy } \\
\text { approach based on the ideal } \\
\text { and aegative ideal solutions. } \\
\text { Theyshorred that this method } \\
\text { is very efficie at and } \\
\text { applicable }\end{array}$ \\
\hline 11 & [14] & $\begin{array}{l}\text { Numerical } \\
\text { example }\end{array}$ & $\begin{array}{l}\text { Furvy multiple } \\
\text { criteria goals }\end{array}$ & $\begin{array}{l}\text { The general MCDNP problem } \\
\text { is solved mhere both the goals } \\
\text { and the coefficie ats are } \\
\text { tre ated simultaneously. }\end{array}$ \\
\hline 12 & [15] & $\begin{array}{l}\text { Numerical } \\
\text { example }\end{array}$ & Fumy & He presented a Fuzry DNP \\
\hline 13 & [16] & $\begin{array}{l}\text { Numerical } \\
\text { example }\end{array}$ & Multi-criteria & $\begin{array}{l}\text { He proposed several } \\
\text { optimum-path ratios on } \\
\text { different budget levels of } \\
\text { resources to find the } \\
\text { alternative of optinal system } \\
\text { designs for solving MCDNP } \\
\text { problems. }\end{array}$ \\
\hline
\end{tabular}

Continue Table 1

\begin{tabular}{|c|c|c|c|c|}
\hline No & $\begin{array}{l}\text { Author(s) } \\
\text { Ref. No. }\end{array}$ & Application & $\begin{array}{l}\text { Single / multi } \\
\text { - objectives }\end{array}$ & Method \\
\hline 14 & {$[17]$} & $\begin{array}{c}\text { Production } \\
\text { program }\end{array}$ & multi-criteria & $\begin{array}{l}\text { They presented the } \\
\text { possibilitities for optimal } \\
\text { production plan design using } \\
\text { MICDNP approach. }\end{array}$ \\
\hline 15 & [16] & $\begin{array}{c}\text { Budget } \\
\text { arailability and } \\
\text { possible debt }\end{array}$ & multi criteria & $\begin{array}{l}\text { He made the frame work of } \\
\text { the system design model using } \\
\text { a MCDNP approach. }\end{array}$ \\
\hline 16 & [18] & $\begin{array}{l}\text { Production } \\
\text { system }\end{array}$ & Single & $\begin{array}{l}\text { He summarized the basic } \\
\text { formalism of DNP as it } \\
\text { applies to linear systems. }\end{array}$ \\
\hline 17 & [19] & $\begin{array}{l}\text { Numerical } \\
\text { example }\end{array}$ & & $\begin{array}{l}\text { He dramu attention to the } \\
\text { impossibility of optimization } \\
\text { mhen rariables are given and } \\
\text { present eight basic concepts of } \\
\text { optimality including DNP. }\end{array}$ \\
\hline 18 & [20] & $\begin{array}{l}\text { Strate gic } \\
\text { alliauces }\end{array}$ & & $\begin{array}{l}\text { They provided an optimal } \\
\text { resource portfolio using DNP } \\
\text { in strate gic alliances and RA. }\end{array}$ \\
\hline 19 & [21] & $\begin{array}{l}\text { Numerical } \\
\text { example }\end{array}$ & $\begin{array}{l}\text { Fuzzy multi- } \\
\text { stage dyuamic }\end{array}$ & $\begin{array}{l}\text { They estended the traditional } \\
\text { DNP problem to a DNP } \\
\text { problein with multiple fury } \\
\text { goals, furry constraints and } \\
\text { multiple stages. Then, they } \\
\text { regarded this funzy multi- } \\
\text { stage DNP as a furzy dyaumic } \\
\text { programming }\end{array}$ \\
\hline 20 & [22] & $\begin{array}{l}\text { Production } \\
\text { system }\end{array}$ & multi-criteria & $\begin{array}{l}\text { They combined the MC and } \\
\text { DNP in a production model to } \\
\text { desigu the optimal production } \\
\text { system. }\end{array}$ \\
\hline 21 & [23] & $\begin{array}{l}\text { allocating } \\
\text { optimal } \\
\text { alliance } \\
\text { resources }\end{array}$ & $\begin{array}{l}\text { funzy multi- } \\
\text { objective }\end{array}$ & $\begin{array}{l}\text { They choose the best alliance } \\
\text { partuers and allocating } \\
\text { optimal alliance resources } \\
\text { using the fauzy MO dumy y } \\
\text { programming model }\end{array}$ \\
\hline 22 & [24] & $\begin{array}{l}\text { An education } \\
\text { resources } \\
\text { allocation }\end{array}$ & & $\begin{array}{l}\text { They formulated RA model } \\
\text { using DNP for school by } \\
\text { integrating information } \\
\text { technology into instruction to } \\
\text { achieve the aspired desired } \\
\text { level. }\end{array}$ \\
\hline 23 & [25] & $\begin{array}{l}\text { Eaviromnent- } \\
\text { watershed } \\
\text { resource } \\
\text { mangement }\end{array}$ & $\begin{array}{l}\text { fungy multi- } \\
\text { Criteria } \\
\text { decision } \\
\text { making }\end{array}$ & $\begin{array}{l}\text { They combined DNP mith } \\
\text { Multiple objective decisions } \\
\text { making to solve resource } \\
\text { allocation proble ms for } \\
\text { Euriroument-watershed } \\
\text { resource management. }\end{array}$ \\
\hline 24 & [26] & $\begin{array}{l}\text { strate gic } \\
\text { alliances and } \\
\text { resource } \\
\text { allocation in } \\
\text { supply chain }\end{array}$ & Supply chain & $\begin{array}{l}\text { They used the DNP approach } \\
\text { as a strategic alliance } \\
\text { alternative to achieve optimal } \\
\text { RA in SC systems. }\end{array}$ \\
\hline
\end{tabular}




\section{Continue Table 1Continue Table 1}

\begin{tabular}{|c|c|c|c|c|}
\hline No & $\begin{array}{l}\text { Author(s) } \\
\text { Ret. No. }\end{array}$ & Application & $\begin{array}{l}\text { Single / multi } \\
\text { - objectives }\end{array}$ & Method \\
\hline 25 & [27] & $\begin{array}{l}\text { water } \\
\text { resources } \\
\text { systems }\end{array}$ & & $\begin{array}{l}\text { They coasidered ine ract DNP } \\
\text { for mater resources systems } \\
\text { planning }\end{array}$ \\
\hline 26 & [28] & $\begin{array}{l}\text { Economic } \\
\text { Proble mI }\end{array}$ & $\begin{array}{l}\text { multidime asion } \\
\text { al }\end{array}$ & $\begin{array}{l}\text { He introduced multi- } \\
\text { dimension of an economic } \\
\text { problem }\end{array}$ \\
\hline 27 & [5] & $\begin{array}{l}\text { Numerical } \\
\text { example }\end{array}$ & Multi objective & $\begin{array}{l}\text { He explained the terras of No } \\
\text { optimization \& discussed the } \\
\text { role of trade offs-based versas } \\
\text { trade offs-free thinking using } \\
\text { DNP }\end{array}$ \\
\hline 28 & [29] & $\begin{array}{l}\text { Illustrative } \\
\text { example }\end{array}$ & Multi objective & $\begin{array}{l}\text { He presented approaches for } \\
\text { solving the multi objective } \\
\text { DNP problem, exteasions, } \\
\text { examples, and applications. }\end{array}$ \\
\hline 29 & [30] & $\begin{array}{l}\text { Supply chain } \\
\text { problem }\end{array}$ & $\begin{array}{l}\text { Multiple } \\
\text { Objectives }\end{array}$ & $\begin{array}{l}\text { He used DNP for optimal } \\
\text { system de sigu resbaping the } \\
\text { feasible set in line ar systems. } \\
\text { He formulated \& solved the } \\
\text { SC problem using DNP. }\end{array}$ \\
\hline 30 & [31] & $\begin{array}{l}\text { Single city } \\
\text { water supply in } \\
\text { Texas }\end{array}$ & $\begin{array}{l}\text { Water supply } \\
\text { portfolio } \\
\text { planning } \\
\text { Mauy-objective } \\
\text { Cuder } \\
\text { wcertainty }\end{array}$ & $\begin{array}{l}\text { They presented DNP to and } \\
\text { uncertainty mithin water } \\
\text { manage me nt problems by } \\
\text { coupling global seasitivity } \\
\text { analysis using Sobol' variance } \\
\text { decomposition with MIO } \\
\text { evelutionary algorithms. }\end{array}$ \\
\hline 31 & [32] & & $\begin{array}{l}\text { MIalti-stage } \\
\text { and wulti- } \\
\text { objective }\end{array}$ & $\begin{array}{l}\text { They suggested a uew } \\
\text { approaxh to solve multi-stage } \\
\text { \&MODM proble w usiag DNP }\end{array}$ \\
\hline 32 & [33] & $\begin{array}{l}\text { Taiwan } \\
\text { Freenay's } \\
\text { maintenance } \\
\text { work system } \\
\text { (Pavement } \\
\text { Maiutemance) }\end{array}$ & $\begin{array}{c}\text { Multi- } \\
\text { objectives goal }\end{array}$ & $\begin{array}{l}\text { They used MOGP to solve } \\
\text { priority with the pavement } \\
\text { maintenance works in the } \\
\text { pavement manage ment using } \\
\text { the De Novo method to } \\
\text { approash the ideal point. }\end{array}$ \\
\hline 33 & [34] & $\begin{array}{l}\text { Numerical } \\
\text { example }\end{array}$ & $\begin{array}{l}\text { Multi-objective } \\
\text { DMI }\end{array}$ & $\begin{array}{l}\text { They applied DNP technique } \\
\text { for optimal desizu of a } \\
\text { system. The adrantage of the } \\
\text { proposed approach is that it } \\
\text { requires less number of } \\
\text { vainables, thus reducing the } \\
\text { processing time. }\end{array}$ \\
\hline 34 & [35] & $\begin{array}{l}\text { Numerical } \\
\text { example }\end{array}$ & $\begin{array}{l}\text { malti-objective } \\
\text { Goal }\end{array}$ & $\begin{array}{l}\text { He suggested DNP and Min- } \\
\text { max GP approaches using } \\
\text { positive and afgatice ideals. } \\
\text { He identified compromise } \\
\text { solutions using rain-max } \\
\text { approach }\end{array}$ \\
\hline 35 & [36] & $\begin{array}{l}\text { A production } \\
\text { system that } \\
\text { produces four } \\
\text { types of plas tic } \\
\text { balls }\end{array}$ & $\begin{array}{l}\text { Gobal } \\
\text { Criterion } \\
\text { Method }\end{array}$ & $\begin{array}{l}\text { They built an optimum } \\
\text { Production Settings solving } \\
\text { the problem using Global } \\
\text { Criterion Method nith DNP. } \\
\text { It is seen that both Global } \\
\text { Criterion Method and De } \\
\text { Novo solutions give the same } \\
\text { valaes. }\end{array}$ \\
\hline
\end{tabular}

\begin{tabular}{|c|c|c|c|c|}
\hline No & $\begin{array}{c}\text { Author(s) } \\
\text { Ref No. }\end{array}$ & Application & $\begin{array}{l}\text { Single / multi } \\
\text { - objectives }\end{array}$ & Method \\
\hline 36 & [37] & $\begin{array}{l}\text { Planning water } \\
\text { resources } \\
\text { systems }\end{array}$ & $\begin{array}{c}\text { interval-fuuy } \\
\text { DNP }\end{array}$ & $\begin{array}{l}\text { They used an interval-fuzy } \\
\text { DNP for planning water } \\
\text { resources systems under } \\
\text { uncertainty }\end{array}$ \\
\hline 37 & [35] & $\begin{array}{l}\text { IC Design } \\
\text { Service Firms } \\
\text { Resources } \\
\text { Integration }\end{array}$ & $\begin{array}{l}\text { Resource } \\
\text { integration }\end{array}$ & $\begin{array}{l}\text { He Adopted the DNP to belp } \\
\text { fins to find out an optimal } \\
\text { resource integration base on } \\
\text { fin financial consider. They } \\
\text { planed model provided } \\
\text { reliable systematize approach } \\
\text { that combines alliances from } \\
\text { external resources and change } \\
\text { them to internal resources } \\
\text { application. }\end{array}$ \\
\hline 38 & [39] & Supply chaie & $\begin{array}{c}\text { Furzy } \\
\text { programming }\end{array}$ & $\begin{array}{l}\text { They developed a DNP to } \\
\text { determine the capacity of } \\
\text { recovery facilities in the } \\
\text { reverse flom. A mired integer } \\
\text { NLP model is integrated with } \\
\text { the DNP and the robust } \\
\text { counterpart model is } \\
\text { proposed nifh uncertainty. } \\
\text { So, interactive fuzzy approach } \\
\text { combined with the hard worst } \\
\text { case robust prog. }\end{array}$ \\
\hline 39 & [40] & $\begin{array}{l}\text { Bi-objective } \\
\text { location } \\
\text { allocation } \\
\text { imrentory } \\
\text { netrork }\end{array}$ & $\begin{array}{l}\text { Single- } \\
\text { objective \& } \\
\text { bi-objective }\end{array}$ & $\begin{array}{l}\text { First stage, they proposed a } \\
\text { single-objective model to } \\
\text { minimize the total costs. In } \\
\text { second stage, they used DNP } \\
\text { to deternine the optimal } \\
\text { capacity to select supplier(s). } \\
\text { They proposed bi-objective } \\
\text { mix-integer monlinear model } \\
\text { to solve the problem. }\end{array}$ \\
\hline 40 & [41] & $\begin{array}{l}\text { Numerical } \\
\text { example }\end{array}$ & $\begin{array}{l}\text { Fuxzy multi- } \\
\text { objective }\end{array}$ & $\begin{array}{l}\text { They presented an alternative } \\
\text { approach to solve the general } \\
\text { MODNP Problem under } \\
\text { fuzzy environment in one step } \\
\text { using Luhandjula's } \\
\text { compensatory } \mu_{G} \text { operator. }\end{array}$ \\
\hline 41 & [42] & $\begin{array}{l}\text { Build wind } \\
\text { energy sites }\end{array}$ & Multi-criteria & $\begin{array}{l}\text { The objectives of DNP are } \\
\text { converted into meta-goals } \\
\text { reaching to the most } \\
\text { satisfactory decision in the } \\
\text { MODM context. }\end{array}$ \\
\hline 42 & [43] & $\begin{array}{l}\text { Numerical } \\
\text { example }\end{array}$ & $\begin{array}{l}\text { Fuzzy Multi- } \\
\text { criteria \& GP }\end{array}$ & $\begin{array}{l}\text { Furzy goal programming } \\
\text { approach is applied on } \\
\text { MCDNP }\end{array}$ \\
\hline 43 & [44] & $\begin{array}{l}\text { Illustrative } \\
\text { example }\end{array}$ & $\begin{array}{l}\text { Multi-objective } \\
\text { goal } \\
\text { programming }\end{array}$ & $\begin{array}{l}\text { The wrighted GP has been } \\
\text { used and only one deviation } \\
\text { variable has been taken. }\end{array}$ \\
\hline 44 & [45] & $\begin{array}{l}\text { be achmarking } \\
\text { proble ms }\end{array}$ & $\begin{array}{c}\text { Multi- } \\
\text { Objective }\end{array}$ & $\begin{array}{l}\text { The average concept is } \\
\text { applied to the GP model to } \\
\text { solve the MODNP. The } \\
\text { computational results with } \\
\text { benchmark problems showed } \\
\text { that the proposed method } \\
\text { gives satisfactory results and } \\
\text { more practical }\end{array}$ \\
\hline
\end{tabular}




\section{Comment on analysis}

$28 \%$ of the applications used in production planning to find the optimum resource portfolio for different type of products (Plastic balls, wood utilization, ferroalloys, clothes, hardware, software, and health care), 24\% used in Strategic planning (strategic alliances, funding, supply chains, and inventory design), $10 \%$ used in improvement \& maintenance (pavement maintenance, Freeway's maintenance, and watershed resource maintenance), $10 \%$ used in project installation (installing wind energy farm, water supply portfolio, and building an education system), and $28 \%$ on other types of different applications. The DNP technique made a new evolution for the concept of optimality. This technique is more helpful for the decision maker to allocate the optimum resource portfolio specially while having tradeoffs between the objectives of the multi criteria decision making problems to meet the ideal point of the solution which is frequently outside the feasible set of solutions. The most critical problem with the DNP is that the required budget could be exceed the subject budget using the DNP, so that the optimum path ratio in some situations is used to avoid the raised level of required budget related to the available one.

\section{Conclusion}

The DNP is a technique which uses to redesign a system reaching to the optimal solution. A brief review of DNP is presented in this paper, then analysis and summary of the literature review. Applications of DNP for various optimization problems are also discussed.

\section{References}

[1] M. Zeleny, Mathematical programming with multiple objectives (special issue), Comput. Oper. Res. 7, 101-107, (1980).

[2] M. Zeleny, Optimal system design with multiple criteria: De-Novo Programming approach, Engineering Costs and Production Economics, 10, 89-94, (1986).

[3] M. Zeleny, Optimizing given systems vs. designing optimal systems: The de novo programming approach, International journal of general systems, 17 (4), 295-307 (1990).

[4] M. Zeleny, On the squandering of resources and profits via linear programming,Interfaces11(S) 101-107 (1981).

[5] M. Zeleny, The elimination of tradeoffs in modern business and economics, in New Frontiers of Decision Making for the Information Technology Era, ed: World Scientific, pp. 173-195, (2000).

[6] Y. Shi, Studies on Optimum-Path Ratios in De Novo Programming Problems, Computers and Mathematics with Applications 29 pp. 43-50, (1995).

[7] M. Zeleny, A Case Study in Multi-objective Design: De-Novo Programming, in Multiple Criteria Analysis: Operational Methods, Gower publishing Co., Hampshire, 37-52, (1981a).

[8] M. Hessel and M. Zeleny, Optimal system designs: Towards new interpretation of shadow prices in linear programming, Computers and Operations Research, v.14, I 4, 265-271, (1987)

[9] B. B. Bare \& G. A. Mendoza, A soft optimization approach to forest land management planning, Canadian journal of forest research, 18(5), 545-552, (1988).

[10] M. T. Tabucanon, Multiple criteria decision making in industry, (Vol. 8). Elsevier Science Ltd (1988).

[11] B. B. Bare \& G. A. Mendoza, Designing forest plans with conflicting objectives using de Novo programming, Journal of environmental management, 31(3), 237-246, (1990).

[12] R. J. Li and E. S. Lee, Fuzzy Approaches to Multi-criteria De Novo Programs. Journal of Mathematical Analysis and Applications 153 pp. 97-111, (1990).

[13] R. J. Li \& E. S. Lee, Multi-criteria de novo programming with fuzzy parameters. Journal of mathematical analysis \& application, 19(1), 13-20 (1990)

[14] R. J. Li \& E. S. Lee, De Novo programming with fuzzy coefficients and multiple fuzzy goals, Journal of mathematical analysis \& applications, 172(1), 212-220, (1993).

[15] E. S. Lee, On Fuzzy De Novo Programming, in: Fuzzy Optimization: Recent Advances, edited by M. Delgado, Kacprzyk, Verdegay and Vila, (Physica-Verlag, Heidelberg, pp. 33-44, 
(1994).

[16] Y. Shi, Optimal system design with multiple decision makers and possible debt: a multicriteria de novo programming approach, Oper. Res. 44 (5), 723-729, (1999).

[17] Z. Babic, and I. Pavic, Multicriterial production planning by de novo programming approach, Int. J. Prod. Econ. 43 (1), 59-66, (1996).

[18] M. Zeleny, The elimination of tradeoffs in modern business and economics, in New Frontiers of Decision Making for the Information Technology, Era, ed: World Scientific, pp. 173-195, (2000).

[19] M. Zeleny, Optimization, Optimal design and De-Novo Programming: Discussion Notes (New York, USA: Fordham University), (2005).

[20] J. J. Huang, G. H. Tzeng and C. S. Ong, Motivation and resource-allocation for strategic alliances through the De Novo perspective, Mathematical and Computer Modeling, vol. 41, pp. 711-721, (2005).

[21] Y. W. Chen \& H. E. Hsieh, Fuzzy multi-stage De-Novo programming problem, Applied mathematics and computation, 181 (2), 1139-1147, (2006).

[22] Z. Babić, T. Hunjak, and I. Veža, Optimal System Design with Multi-criteria Approach, Global Business Economics Anthology, vol. 1, pp. 493-502, (2006).

[23] J. J. Huang, G. -H. Tzeng and C. -S. Ong, Choosing best alliance partners and allocating optimal alliance resources using the fuzzy multi-objective dummy programming model, Oper. Res. Soc. 57 (10), 1216-1223, (2006).

[24] J. K. Chen, K. C. Chen, S. Y. Lin and B. J. Yuan, Build an education resources allocation planning model of school with integrating Information Technology, in Industrial Engineering and Engineering Management, IEEE International Conference, pp. 1268-1274, (2008).

[25] Y. C. Chen, J. J. Liou, H. P. Lien and G. H. Tzeng, Fuzzy Multiple-Criteria-Decision-Making Approach for Environment, Watershed, (2008).

[26] J. K. Chen and G. H. Tzeng, Perspective strategic alliances and resource allocation in supply chain systems through the De Novo programming approach, International Journal of Sustainable Strategic Management, vol. 1, pp. 320-339, (2009).

[27] Y. M. Zhang, G. H. Huang \& X. D. Zhang, Inexact de Novo programming for water resources systems planning, European journal of operational research, 199(2), 531-541, (2009).

[28] M. Zeleny, On the essential multidimensionality of an Economic Problem: Towards tradeoffs-free Economics, AUCO Czech Economic Review 3, 154-175, (2009).

[29] P. Fiala, Multi-objective De Novo Linear Programming, Acta. univ. atispalackiana. Facultasrerumnaturalium. Mathematica, V50,(2), 29-36, (2011).

[30] P. Fiala, Design of Optimal Linear Systems by Multiple Objectives, Multiple Criteria Decision Making, University of Economics in Katowice, V 7, pp 71-85, (2012).

[31] J. R. Kasprzyk, P. M. Reed, G. W. Characklis, and B. R. Kirsch, Many-objective de Novo water supply portfolio planning under deep uncertainty, Environmental Modeling \& Software, V 34, pp. 87-104, (2012).

[32] S. Chackraborty, and D. Bhattacharya, A new approach for solution of multi-stage and multi-objective decision-making problem using de novo programming, Eur. J. Sci. Res. 79(3),393-417, (2012).

[33] C. T. Hung, J. D. Lin and P. Liu, Apply De Novo Programming in Pavement Maintenance Strategy Optimization, in Advanced Materials Research, pp. 805-811, (2013).

[34] S. Chakraborty, and D. Bhattacharya, Optimal system design under multi-objective decision making using De-Novo concept: A new approach, International J. of Computer Applications, V 63 (12), 20-27, (2013).

[35] N. Umarusman, Min-Max Goal Programming Approach For Solving Multi-Objective De Novo Programming Problems, International Journal of Operations Research, vol. 10, pp. 92 99, (2013).

[36] N. Umarusman, and A. Turkmen, Building Optimum Production Settings using De Novo Programming with Global Criterion Method, International Journal of Computer Applications, vol. 82, (18), 12-15, (2013). 
[37] D. Miao, Y., W. Huang, W., Y. Li, P. and Z. Yang, F. Planning water resources systems under uncertainty using an interval-fuzzy de novo programming method, J. Environ. Inform. 24 (1), 11-23, (2014).

[38] J. Chen, Adopting De Novo Programming Approach on IC Design Service Firms Resources Integration, Mathematical Problems in Engineering, V 2014, Article ID 903056, 13 pages, (2014).

[39] S. Saeedi, M., Mohammadi, and S. Torabi, A de novo programming approach for a robust closed-loop supply chain network design under uncertainty: An m/m/1 queuing model, Int. J. Ind. Eng. Comput. 6 (2), 211-228, (2015).

[40] F. R. Tezenji, M. Mohammadi and S. H. R. Pasandideh, Bi-objective location-allocationinventory-network design in a two-echelon supply chain using de novo programming, NSGA-II and NRGA, I. J of Logistics Systems \& Management, V 28, N 3, P. 308-337, (2017).

[41] D. Bhattacharya and S. Chakraborty, Solution of the general multi-objective De-Novo programming problem using compensatory operator under fuzzy environment, international Journal of Physics: Conference Series, V 1039, p.27-29, (2018).

[42] Z. Y. Zhuang and A. Hocine, Meta goal programing approach for solving multi-criteria de Novo programing problem, European Journal of Operational Research, vol. 265 (1) pp. 228$238,(2018)$.

[43] H. Khalifa, On Solving Fully Fuzzy Multi-criteria De Novo Programming via Fuzzy Goal Programming Approach, Journal of Applied Research on Industrial Engineering, V. 5, No. 3 239-252, (2018).

[44] S. Banik, and D. Bathacarya, Weighted goal programming approach for solving multiobjective de novo programming problems, International Journal of Engineering Research in Computer Science and Engineering, vol. 5, I. 2, pp. 316 -322, (2018)

[45] F. Afli, I. Hasbiyati, and M. D. H. Gamal, Modification Goal Programming for Solving Multi-Objective De Novo Programming Problems, Int. J. of Management and Fuzzy Systems, V5, I 4, P 64-69, (2019). 